\title{
The Correlation Between Unilateral Posterior Teeth and Articular Inclination of the Temporomandibular Using the Panoramic Radiograph
}

\author{
Diah Indriastuti ${ }^{1}$, Sari Dewiyani ${ }^{2}$, Narlan Sumawinata ${ }^{3}$, Jatu Rachel Keshena ${ }^{4}$ \\ \{diah.manung@gmail.com ${ }^{1}$, sari.drg@gmail.com ${ }^{2}$, n_sumawinata@yahoo.com ${ }^{3}$, \\ jaturacheel@gmail.com ${ }^{4}$ \} \\ ${ }^{1}$ Dentomaxillofacial Radiology Department, Faculty of Dentistry, Prof. Dr. Moestopo \\ (Beragama) University, Jakarta, Indonesia \\ ${ }^{2,3}$ Dentistry Conservation Department, Faculty of Dentistry, Prof. Dr. Moestopo \\ (Beragama) University, Jakarta, Indonesia \\ ${ }^{4}$ PPDGS Resident Radiology Dentistry, Faculty of Dentistry, Padjajaran University, \\ Bandung, Indonesia
}

\begin{abstract}
Alteration of Temporomandibular joint is part of the stogmatonagti. The prevalence of joint disorders is $10-70 \%$ most cases have lost mandibular molars. This research will the alteration of articular eminence inclination on temporomandibular joint between patients that loss the unilateral mandibular posterior teeth and patients with mandibular posterior teeth using panoramic x-ray. Analytic research cross-sectional study design. Data analysis was performed using an independent T-test with p-value = 0.05 . $T$ will be count as the average deviation of EA (eminensia artikularis) angle with sig value (P-Value) of 0,009 less, out of 0,05 or $\alpha<p(p=0,05)$ showing that there is an articular eminence inclination differences between patients that loss the unilateral mandibular posterior teeth and patients with mandibular posterior teeth.Conclusion : There is a connection between losing the unilateral mandibular posterior teeth with articular eminence inclination on temporomandibular joint.
\end{abstract}

Keywords: Panoramic Radiograph, Articular Eminence

\section{Introduction}

In this research, the writer is interested in ELSEVIER Journal written by Meng-TaChiang with the total of 106 joints in 53 patients (20 male \& 33 female) with uni-lateral posterior edentulism. Edentulous right posterior result of $27 \%$ each individual with the average value of Articular Eminence (AE) slope is 37,7 indicate the slope angle on the non missing side were increasing compared to the missing side observed $(\mathrm{P}>0,05)$ was considered to be significant. The inclination of $\mathrm{AE}$ in men was higher than in women on both the missing side and the non-missing side $(\mathrm{P}>0.05)$. The symmetry equality between the missing and the non-missing side joint was $1.89 \%$. This value was higher $(3 \%)$ in the female group with the average of 52 years old in the range of age between 23 to 84 years old [1]. Meanwhile, based on data survey of Riset Kesehatan Dasar (RisKesDas) in 2007 the dental care condition of dentures user in Indonesia was around 4,5\% [2]. Riset Kesehatan Dasar (RisKesDas) is one of the national scale community based researcher that has been continuously conduct by Badan Penelitian dan Pengembangan Kesehatan (Litbangkes) of Health Care Ministry of Indonesian 
Republic which the result has become the foundation of planning, controlling and evaluating for health care program in the scale of national and province.

Based on the continuously researches on the 2007, $2010 \& 2013$, [3] the writer interested on having a research about dental care condition in Indonesia, especially one of the cause of prevalent dentures user were still 4,5\% which causing the possibilities of loosing posterior teeth will create changes on TMJ. So, the purpose of this research is to explain some changes in the tendency of articular eminence of the temporomandibular joint in patients using Panoramic X-ray with and without unilateral loss of posterior teeth. The temporomandibular joint is part of the stomatognathic system. The prevalence disorder of temporomandibular joint is $10-70 \%$ and most cases have lost mandibular molars. [4], [5], [6].

Panoramic is creating images of the temporomandibular joint, maxilla, mandible, maxillary sinus, teeth and periodontium tissue. Panoramic images show two-sided (bilateral) condylarine and subcondylary regions, and shows degenerative changes of the temporomandibular joint, pathological changes from the maxilla and mandible. In panoramic images, the x-ray beam that travel from the posterior-inferior direction causes the lateral part of the condyle to overlap with the condyle head so that the demineralization of the temporomandibular joint cannot be seen. Similar with the articular eminence that overlaps in panoramic photos. Overlap from glenoidal fossa to above the condyle. [7] Panoramic images are useful and helpful to detect a pathological conditions, impacted teeth and to evaluate the eruption of the development and growth of permanent and milk teeth and also detect temporomandibular joint and vertical alveolar bone problem. [8], [9], [10], [11], [12], [13] The purpose of the research with panoramic image is to explain the missing connection between the unilateral of the mandibular posterior teeth and the articular eminence inclination at the temporomandibular joint.

\section{Methods and Materials}

This is an analytic research using cross-sectional study design. This research being conduct based on the photo panoramic samples of 60 patients from The Dental and Oral Hospital, Faculty of Dentistry, University of Prof. Dr. Moestopo (Beragama), Jakarta, Indonesia with the range of age between 16 years old to 56 years old, with the total of 28 male and 32 female, with the case of 30 patients with the unilateral mandibular posterior teeth loss and the other 30 patients without mandibular posterior teeth loss.

Panoramic tracing of the angle of the articular
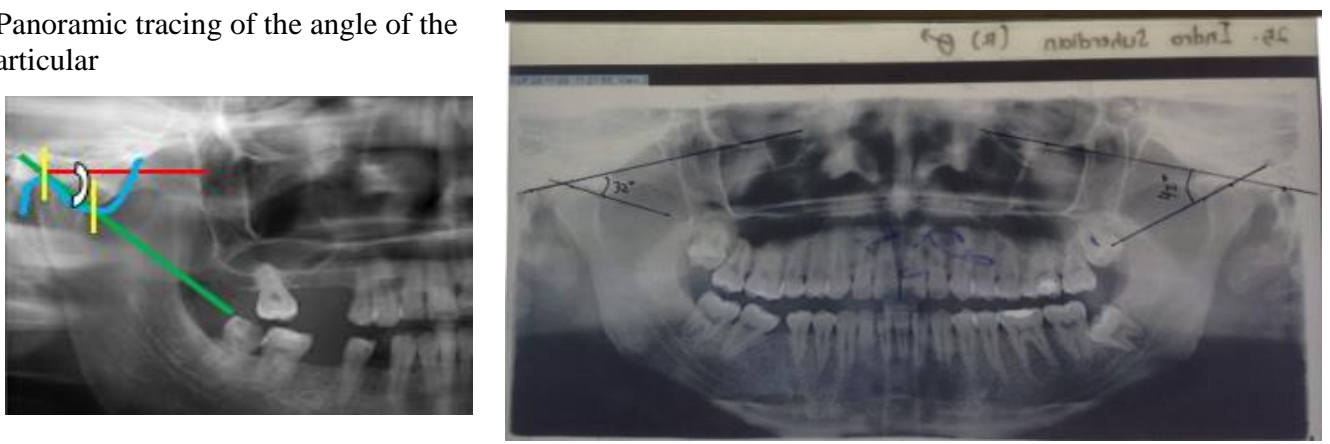

$>$ Operational Data:

- Panoramic Digital: X-RAY

- Brand: SIRONA-ORTHOPHOS 
- Type: SR.90115FN

- No. SERI: 109250

- Model: 5968573 D3200

- Volt: $90 \mathrm{KV} / 12 \mathrm{MA}$

- Program: Panoramic (P1)

- Adults: $64 \mathrm{KV} / 0.8 \mathrm{MA}$

- Operator name: Wahyudin

\section{Result}

The tilt angle of the patient's articular eminence with the mandibular posterior teeth loss are 1,79 times higher compare to patient without mandibular posterior teeth loss. The average differences level are $10,20^{\circ}$. The patient without teeth loss having an average differences level of $5,7^{\circ}$ between the left and the right side of the articular eminence, but there are no significant differences (t-test).

Table 1. (t-test)

\begin{tabular}{lll}
\hline Group & $\begin{array}{c}\text { Amount } \\
(\mathbf{n})\end{array}$ & Percentage \\
\hline $\begin{array}{l}\text { Patients without posterior mandibular } \\
\text { teeth loss }\end{array}$ & 30 & $10,20^{0}$ \\
Patients with posterior mandibular & 30 & $5,70^{0}$ \\
Total & 60 & $100 \%$ \\
\hline
\end{tabular}

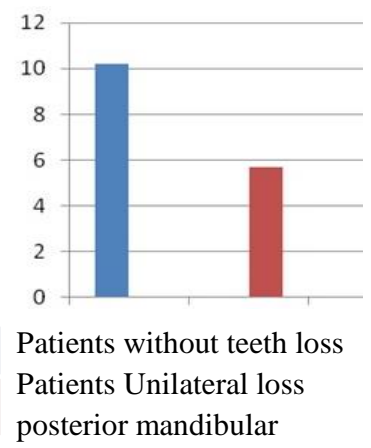

Teble 2. Patient Distribution by Gender

\begin{tabular}{ccc}
\hline Gender & Amount (n) & Percentage \\
& & \\
Male & 28 & $\mathbf{4 6 . 7 \%}$ \\
Female & $\mathbf{3 2}$ & $\mathbf{5 3 , 3 \%}$ \\
Total & $\mathbf{6 0}$ & $\mathbf{1 0 0 , 0 \%}$ \\
\hline
\end{tabular}

Table 3. The frequency distribution of patients is based on $r$ angles that are different from the right and left EA (articular eminence) of Gender

\begin{tabular}{lll}
\hline $\begin{array}{l}\text { EA Difference angle } \\
\text { right and left }\end{array}$ & Amount (n) & Percentage \\
\hline $0^{\circ}$ & 3 & $5.0 \%$ \\
$1^{\circ}$ & 7 & $11.7 \%$ \\
$2^{\circ}$ & 3 & $5.0 \%$ \\
$3^{\circ}$ & 6 & $10.0 \%$ \\
$4^{\circ}$ & 6 & $10.0 \%$ \\
$5^{\circ}$ & 5 & $8.3 \%$ \\
$6^{\circ}$ & 4 & $6.7 \%$ \\
$7^{\circ}$ & 1 & $1.7 \%$ \\
\hline
\end{tabular}




\begin{tabular}{lll}
\hline $8^{\circ}$ & 4 & $6.7 \%$ \\
$10^{\circ}$ & 4 & $6.7 \%$ \\
$12^{\circ}$ & 3 & $5.0 \%$ \\
$13^{\circ}$ & 1 & $1.7 \%$ \\
$15^{\circ}$ & 3 & $5.0 \%$ \\
$17^{\circ}$ & 3 & $5.0 \%$ \\
$18^{\circ}$ & 1 & $1.7 \%$ \\
$20^{\circ}$ & 1 & $1.7 \%$ \\
$21^{\circ}$ & 2 & $3.3 \%$ \\
$23^{\circ}$ & 3 & $5.0 \%$ \\
Total & 60 person & $100.0 \%$ \\
\hline
\end{tabular}

\begin{tabular}{|c|c|c|}
\hline Group & Amount (n) & Percentage \\
\hline $\begin{array}{c}\text { Patients without } \\
\text { posterior mandibular } \\
\text { teeth loss }\end{array}$ & 30 & $50 \%$ \\
\hline $\begin{array}{c}\text { Patients with } \\
\text { posterior mandibular }\end{array}$ & 30 & $50 \%$ \\
\hline Total & 60 & $100 \%$ \\
\hline
\end{tabular}

Table 4. Patient Distribution by Gender

\begin{tabular}{llll}
\hline Number & Age (years) & Number (n) & Percentage (\%) \\
\hline $\mathbf{1 .}$ & $12-16$ & 4 & $6,6 \%$ \\
$\mathbf{2 .}$ & $17-25$ & 30 & $50 \%$ \\
$\mathbf{3 .}$ & $26-35$ & 16 & $26,6 \%$ \\
$\mathbf{4 .}$ & $36-45$ & 8 & $13,6 \%$ \\
$\mathbf{5 .}$ & $46-55$ & 1 & $1,6 \%$ \\
$\mathbf{6 .}$ & $56-65$ & 1 & $1,6 \%$ \\
Total & & 60 person & $100 \%$ \\
\hline
\end{tabular}

Table 5. Test variance homogeneity table of EA difference right and left

\begin{tabular}{cccc}
\hline Levene Statistic & df1 & df2 & Sig. \\
16.432 & 1 & 58 & .000 \\
\hline
\end{tabular}

Based on the data above and also the data variant from the left and right articular eminence angle differences of the homogeneity test result between patient with mandibular posterior teeth loss and patient without mandibular posterior teeth loss, the sig value probability is 0,000 . This result shows that the data variant is unequal because $\mathrm{P}-$ Value $<0,05$.

Table 6. of analysis results using T-Test

\begin{tabular}{ll}
\hline & P-Value \\
Results analysis & 0.009 \\
\hline
\end{tabular}

It shown that the T-Test between left and right EA average angle differences has probabilities of $0,009(\alpha)$ with the result of $\mathrm{H} 0$ got rejected and H1 accepted because $\alpha<p$-value $(0.05)$. Therefore, the conclusion of the EA average differences from both groups (with or without teeth loss) is un-identical.

\section{Discussion}

The frequency distribution differences on mandibular posterior teeth of the EA angle from patients without mandibular posterior teeth loss are 1,79 times bigger than $10,20^{\circ}$ and the average differences between the left and right of the EA angle are $5,7^{\circ}$ (T-Test).

Patients with unilateral mandibular posterior teeth loss and with no probability posterior teeth loss of $0,009(\alpha)$, for $\alpha<p$-value $(0,05)$ with the result of H0 got rejected and H1 accepted. Therefore, the 
average differences of the EA angle between groups with unilateral mandibular posterior test loss and without mandibular posterior teeth loss is different.

\begin{tabular}{cc}
\hline Results of analysis & $\begin{array}{l}\text { P-Value } \\
\text { P-Value }\end{array}$ \\
\hline$\alpha<p-$ value $(0.05)$
\end{tabular}

\section{Conclusion}

The conclusion of the Articular Eminence (EA) angle between groups with and without mandibular posterior teeth loss is different

\section{Acknowledgements}

The work in this paper was continuously supported by Research Institute for Faculty of Dentistry - Prof. Dr. Moestopo (Beragama) University, Jakarta, Indonesia

\section{References}

[1]. M.T Chiang et al. Evaluation of missing-tooth effect on articular eminence inclination of temporomandibular joint. Journal of Dental sciences 2015 ;10; 383-387.

[2]. Magdarina Destri Agtini. Ercentage Of The Artificial Denture Usage In Indonesia.Puslitbang Biomedis dan Farmasi, Media Litbang Kesehatan Volume XX Nomor 2 tahun 2010

[3]. [3] Badan Penelitian Dan Pengembangan Kesehatan Kementerian Kesehatan RI Tahun 2013 (Riset Kesehatan Dasar)

[4]. Chokalingam S, Felicita, SA. Malocclusion and TMJ disease- A review of Literature. Journal of Dental and medical Sciences 2014;3(1);71-73.

[5]. Khasanah AIKL, Priyanto D. The impact of temporomandibular Joint disorders towards Oral health-related quality of life in elderly. Jurnal PDGI 2012;61(3);102-109

[6]. Okeson J.P. Management of temporomandibular disorders and occlusion. Mosby, st Luis. 2008

[7]. Wright EF. Manual of Temporomandibular disorder. USA: WileyBlackwell;2010.p.71-77.

[8]. Frommer HH, Stabulas JJ. Radiology for dental professional. ed.9th. United States of America : Elsevier Mosby,2011.

[9]. Whaites, Eric. Essentials of Dental Radiography and Radiology. ed: 3rd. St Louis Sydney Toronto : Churchill livingstone;200. 152-172.

[10]. Gupta S, Gupta R, RajeevGarg. Partial edentulism and Temporomandibular joint disorder Journal of Dental and medical Sciences 2014;13(12);60-63.

[11]. Gupta SK, Pratibha PK, Bhat KM, Mutalik S, Guddattu V. Non-replaced Mandibular First Molar and Temporomandibular joint Dysfunction. Nepal Jounal of Medical Sciences 2014;3(1);57-62.

[12]. Gray R and Al-Ani Z. Temporomandibular Disorders A Problem-Based Approach. Willey-Blackwell, 2011. P.99-104

[13]. Iannucci JM,Howerton LJ. Dental Radiography Principles and Techniques.United States of America:Elsevier Saunders 2012. 